\title{
Illegal Buildings and Local Finance in New Metropolitan Perspectives
}

\author{
Fabiana Forte ${ }^{1, a}$ \\ ${ }^{1}$ Second University of Naples, Department of Architecture and Industrial Design Luigi Vanvitelli, \\ Via S. Lorenzo ad Septimum, Aversa (CE), Italy \\ ²fabiana.forte@unina2.it
}

Keywords: Illegal Buildings, Local Finance, Metropolitan Area.

\begin{abstract}
Assuming that metropolitan city costs and the available resources for the realization of public facilities and services are scarce, if not minimal, as in the current economic situation, and in the light of a growing problem which is that of illegal buildings, it is no longer possible to continue to ignore financial tools that assume a certain relevance for financing urban regeneration. The issue of illegal buildings is strictly connected to pecuniary sanctions to obtain a "retrospective building permission" (sanatoria) and could represent a significant item of revenue and capital expenditure (or investment) in financing the public city. In this perspective. the article, analyzing the illegal building phenomenon from a local finance perspective, wants to assess the efficiency and effectiveness of revenues deriving from "retrospective building permission" as well as the financial management and urban planning capacity of local authorities. A first exploration, deriving from a departmental research on Terra di Lavoro, concerning the municipality of Casal di Principe in the province of Caserta.
\end{abstract}

\section{Introduction}

Illegal building is a typically Italian phenomenon, also if the challenge of "informal settlements" is widely recognized in international and national programmes fostering sustainable development [1]. In Italy, it is a serious and very old problem that three building amnesties (the last in 2003) could not solve it. In addition to the legal issues, illegal building has also had a strong territorial impact as in many Italian Regions, above all in the South where the phenomenon is particularly accentuated. As in the BES - Benessere Equo e Solidale - Report [2], in Campania Region, where the maximum intensity of the phenomenon has been recorded, in the last decade, it has been estimated that the share of illegal buildings is almost equal to the half of those built legally. The provinces of Naples and Caserta are the most affected by this problem, with many small and medium sized towns having lost their administrative boundaries, while the peri-urban areas are frequently transformed for urban uses by landowners, without any official planning permission and licenses. This settlements are characterised by a low level of physical quality, scarcity of standards and public facilities, compromising territories with a strong rural and agricultural vocation. This scenario recalls the serious problem of "soil consumption" for urban and infrastructural uses that nowadays is one of the main challenges in pursuing sustainable development [3].

The imminent constitution of the "Città metropolitana" (Metropolitan City) in the Italian administrative system, introduced by the reform of local authorities (Law 142/1990) and established by the legislation proposal approved on December 2013 (Delrio Decree n.1542), includes a large core city and smaller surrounding towns that are closely related to it with regard to economic activities and essential public services, as well as to cultural relations and territorial features. The legislation proposal, which is expected to streamline the provinces, forecasts the institution of ten metropolitan cities, including Naples.

Several studies have been carried out to define the Metropolitan Area of Naples with many alternative hypothesis, but the most sustainable seems that based on the awareness of the diffused urbanization processes of the last decades. It considers the Caserta Province as essential, correlating Naples and Caserta in a new Territorial Authority, definable as Campana Metropolitan City [4], as in Figure 1. 

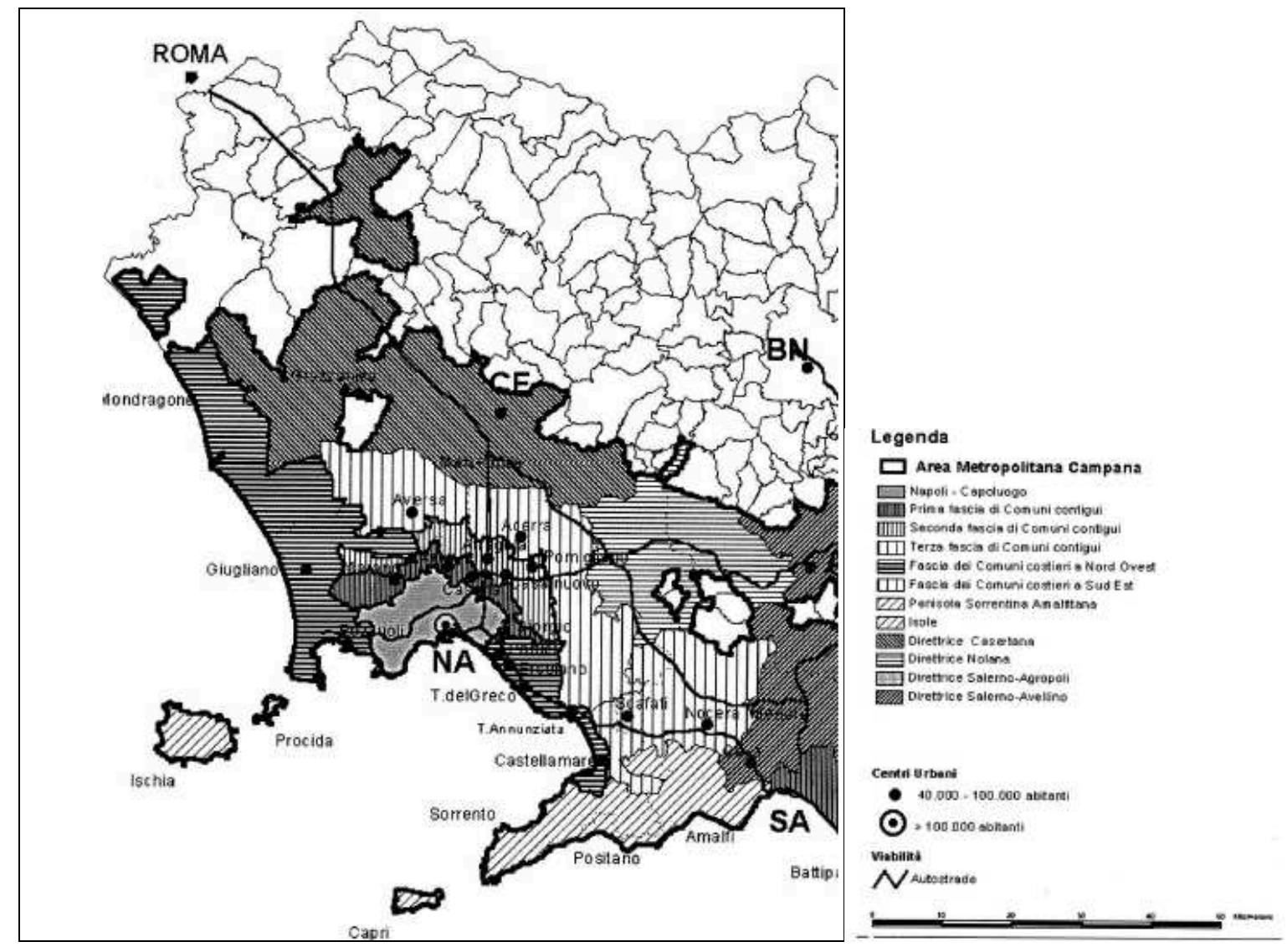

Figure 1: Area Metropolitana Campana, main territorial components (source Fr. Forte, 2013)

In this perspective, the problem of illegal buildings that characterize many municipalities comprised into the overall perimeter of metropolitan area, assumes a certain relevance if it is analyzed from a municipal finance perspective [5]. In fact, the phenomenon is strictly connected to the pecuniary "sanctions" to obtain the "retrospective building permission" (sanatoria), representing a significant item of revenue and capital expenditure (or investment) in financing the public city [6].

Assuming that metropolitan city costs and the resources available for the realization of community facilities and services are scarce, if not minimal, as in the current economic situation, in the face of a growing problem which is that of illegal buildings, it is no longer possible to continue to ignore financial tools that, in numerous municipalities of the arising Metropolitan City, may allow for the recovery of liveability for the community that is widely impaired. In general, the reduction of soil consumption, to be also realized by means of urban regeneration, should become an explicit goal in the implementation of a Metopolitan City Government [7].

In this perspective, to evaluate the efficacy of "retrospective building permission" tools, that can be assimilated to a development or redevelopment charge or contribution for public works (tassazione di scopo), the article wants to investigate the illegal buildings phenomenon from the local finance perspective. Analysis of the latest municipal budgets could help highlight both the efficiency and effectiveness of this tool (if used) as well as the financial management capacity of local authorities [8]. A first exemplification, deriving from a departmental research on Terra di Lavoro, concerning the municipality of Casal di Principe in the province of Caserta is presented in paragraph 3.

\section{Illegal buildings and financial revenues in municipal budget}

Over the last years, "the importance of budgets has grown significantly as cities face increasingly difficult expenditure and revenue decisions in an environment of increased demands of services and 
infrastructure" [9]. According to the Italian legal system, Local Administrations (or Municipalities), on the basis of territorial government rules, concerned with planning and building matters and, above all, they have the faculty to transform urban areas. The right or permission to build is given under the payment of a correspondence public right, a concession fee or "contributo di costruzione" (development charge). This fee, corresponded to the municipality, is inserted into the Municipal Budget, the tool that sets out the local government's plan for revenue and expenditure for an annual or multi-year period.

In the Municipal Budget, revenues are classified with "titles" (six titles) and "category"; the Title IV "Disposal of fixed assets, capital transfers from other governments and private entities" contain "concession fees and sanctions" (permessi di costruire e relative sanzioni) and in this title converge the pecuniary sanctions derived from the violation of the planning and building rules.

The sanctions are established on the basis of Presidential Decree No. 380/01, so called Testo Unico dell'Edilizia, that provides for building activities regulations. Particularly, three forms of sanctions are foreseen: 1) demolition; 2) pecuniary sanction; 3) free acquisition to the municipal assets. For the most relevant works (as new construction or building renovation) without permit, the penal sanction establishes the demolition; for less relevant works, there are pecuniary sanctions, which can vary from $€ 516$ up to the double of the increase of the building value resulting with the realization of the illegal works.

The Decree No. 380/01 also establishes that if the interventions are realized without building permit or in a different way or in absence of statement of the start of works (DIA - Denuncia Inizio Attività) or differently from it, the responsible of illegal works or the actual owner of the building can obtain the permit "in sanatoria" (or the retrospective building permit). This can happen if the intervention are in compliance with the planning and buildings rules in force both at the time of the realization of the building and at the time of presentation of the application. However, in order to obtain the "sanatoria" an amount equal to the double of contribution of construction must be paid.

In this perspective, and considering the illegal building phenomenon, the opportunity of financial recovery that could result from "oblations", along with the concession fees and sanctions should not be underestimated (as has happened up until now), especially in light of the disastrous effects of the current economic recession on the budgets of local authorities, which are forced to deal with increasingly limited resources and an increasingly challenging internal stability pact.

In particular, in the regularization of unauthorized building, the Law of the Campania Region n. 10/2004 article 6 (size of the offering and concession fees, paragraph 3 and 4) already provides that the concession fees relating to unauthorised works under amnesty or sanatoria were increased by one hundred per cent of the amount established by current regulations and that the proceeds from this increase were primarily used by municipalities to meet the expenses necessary for the demolition of unauthorized buildings in their territories, as well as the implementation of measures for the redevelopment of unauthorized buildings.

With the Recovery Plan of Unauthorized Buildings, established by Campania Region Urban Planning Law 16/2004, the regularization process of unauthorized buildings takes a view of the whole and no longer a "case by case" perspective, facing the problem in overall terms, or the urban and environmental redevelopment or regeneration of entire urban areas and, especially, "suburban", that in the province of Naples and Caserta, have developed everywhere, without any planning rules, in the total absence of urbanization and public services, frequently promoted by the expansion of the municipalities in peripheral areas for agricultural use.

In order to implement the plan, "sanctions" play a central role; but also this smart planning tool, aimed at regenerating or redeveloping unauthorized settlements, is still clearly having difficulty getting things off the ground, despite having been in existence for more ten years (there are very few the municipalities in Campania Region which have implemented it).

Moreover, it is important to underline that the revenues from the issuing of "building permits" introduced by Presidential Decree no. 380/2001 (the original former building permit or urbanization charges introduced by Italian Law 10/77) are constrained funds in the budget of the local authority, 
to be used for financing the "public city" (such as the construction of primary and secondary urbanization works as well as the maintenance of the assets, etc.).

In addition, the revenues deriving from retrospective building permit or permit in sanatoria are constrained funds, intended, among the other things, for the demolition of works that are not subject to the amnesty; for interventions of urban and environment redevelopment; for the realization of primary and secondary urbanization works (as in the Law n.662/96). Both the revenues are registered in Municipal Budget at Title IV, but several financial laws during the last decade have contributed to distorting the original nature of these revenues, no longer exclusively finalized at capital expenditure or investments for the municipal infrastructure, but also for current expenditures, in the limit of $50 \%$ of the annual total.

\section{An exemplification: the municipality of Casal di Principe}

As in the Caserta Province Territorial Plan (approved in 2012), approximately 12.000 hectares has been built in absence of the Master Plans and the maximum concentration is in the Caserta and Aversa conurbation as well as the Domitian coast. Municipalities such as Casal di Principe, San Cipriano, Cancello Arnone, Villa Literno, Castel Volturno, etc., already notorious because of organized crime [10], present a very high amount of illegally developed areas and it is not a case that are under judicial administration as a consequence of illegal building practices.

In particular, the municipality of Casal di Principe (21.000 inhabitants), object of a first exploration [11], is characterized by a strong deficiency of standard areas: the amount of planned public equipment should be 44,4 hectares while the amount of existing public equipment is only 6,1 hectares; most of the $35 \%$ of the urbanized area is illegal, concentrated in the Agricultural Area of the Master Plan.

Analyzing the Municiapl Budget over the last five years, it is composed by two main financial documents: the preliminary budget (bilancio di previsione) and the final budget (conto consuntivo). With specific reference to the final budget, Table 1 shows a synthesis of the main revenues; in particular, the revenues deriving from the Title 4.05 "concession fees and sanctions" (not specified from the two different entries ${ }^{1}$ ) show a significant decrease, especially during 2012 (see Table 2). In 2008 and 2009, the years with the most relevant revenues, the main amount comes from concession fees, no longer restricted to the investment expenditure for public facilities and urban recovery, but also usable for the current one, in spite of their original nature of development or redevelopment charges.

The decrement of revenues aimed to realise public facilities is accompanied to a diminution of expenditures for investments. Generally, municipal expenditures are classified in 4 main titles or functions and analyzing the current expenditures (Titles II of Budget) in the last years (Table 3), it is possible to verify a deep contraction in the functions concerning urban planning and territorial and environmental management.

Table 1 : Municipal Final Budget: revenues (2012-2008)

\begin{tabular}{|c|c|c|c|c|c|c|c|c|c|c|}
\hline \multirow{2}{*}{ Municipal Revenues } & \multicolumn{2}{|l|}{2012} & \multicolumn{2}{|l|}{2011} & \multicolumn{2}{|l|}{2010} & \multicolumn{2}{|l|}{2009} & \multicolumn{2}{|l|}{2008} \\
\hline & $\bar{\epsilon}$ & $\%$ & $\bar{\epsilon}$ & $\%$ & $\bar{\epsilon}$ & $\%$ & $\bar{\epsilon}$ & $\%$ & $\epsilon$ & $\%$ \\
\hline TITOLO I ENTRATE TRIBUTARIE & $6.958 .904,78$ & 63 & $6.687 .283,46$ & 33 & $3.384 .550,95$ & 27 & $4.180 .773,78$ & 22 & $3.920 .809,57$ & 24 \\
\hline TIT. II TRASFERIMENTI e CONTRIBUTI & $1.397 .325,28$ & 13 & $1.111 .025,35$ & 5 & $4.303 .054,93$ & 35 & $4.444 .709,07$ & 23 & $5.874 .285,63$ & 35 \\
\hline TIT. III ENTRATE EXTRATRIBUTARIE & $242.893,20$ & 2 & $109.783,42$ & 1 & $145.873,45$ & 1 & $230.521,99$ & 1 & $322.908,04$ & 2 \\
\hline TIT. IV ENTRATE DA ALIEN,TRASF. RISC.CREDITI & $679.175,39$ & 6 & $6.057 .543,14$ & 30 & $1.892 .685,64$ & 15 & $6.515 .151,81$ & 34 & $3.084 .863,02$ & 19 \\
\hline TIT. V ENTRATE DERIVANTI DA ACCENSIONI DI PRES & - & - & $4.778 .526,92$ & 24 & $912.314,74$ & 7 & $787.980,54$ & 4 & 2.182.877,10 & 13 \\
\hline TIT. VI. ENTRATE DA SERVIZI PER CONTO DI TERZI & $1.754 .948,20$ & 16 & $1.457 .060,23$ & 7 & $1.820 .758,52$ & 15 & $3.192 .555,70$ & 16 & $1.229 .654,28$ & 7 \\
\hline Totale & $11.033 .246,85$ & 100 & $20.201 .222,52$ & 100 & $12.459 .238,23$ & 100 & $19.351 .692,89$ & 100 & $16.615 .397,64$ & 100 \\
\hline Fondo cassa 1 gennaio & \multicolumn{2}{|c|}{$3.135 .399,14$} & \multicolumn{2}{|c|}{$1.664 .670,65$} & \multicolumn{2}{|l|}{$3.576 .877,96$} & \multicolumn{2}{|l|}{$1.607 .756,55$} & \multicolumn{2}{|c|}{$6.993,55$} \\
\hline Totale generale delle entrate & \multicolumn{2}{|l|}{$14.168 .645,99$} & \multicolumn{2}{|l|}{$21.865 .893,17$} & \multicolumn{2}{|l|}{$16.036 .116,19$} & \multicolumn{2}{|l|}{$20.959 .449,44$} & \multicolumn{2}{|l|}{$16.622 .391,19$} \\
\hline
\end{tabular}

\footnotetext{
${ }^{1}$ It is important underline that some information or data do not result available in any institutional data bank on municipal bases; in particular, for the revenues deriving from the Title 4.05 "concession fees and sanctions" it was very difficult deducing the differentiation between the two different forms of revenue: building permit and permit in "sanatoria".
} 
Table 2: Focus on Title IV

\begin{tabular}{|c|c|c|c|c|c|c|c|c|c|c|}
\hline \multirow{2}{*}{ Focus on Title IV } & \multicolumn{2}{|l|}{2012} & \multicolumn{2}{|l|}{2011} & \multicolumn{2}{|l|}{2010} & \multicolumn{2}{|l|}{2009} & \multicolumn{2}{|l|}{2008} \\
\hline & $€$ & $\%$ & $\epsilon$ & $\%$ & $\epsilon$ & $\%$ & $\epsilon$ & $\%$ & $€$ & $\%$ \\
\hline 4.01 CESSIONE BENI DEMANIALI & & & & & $2.280,15$ & 0,12 & $5.022,51$ & 0,08 & $23.254,93$ & 0,75 \\
\hline 4.02 TRASFERIMENTI STRAORDINARI DALLOSTATO & & & $4.950 .541,63$ & 81,7 & & & $631.777,33$ & 9,7 & & 0 \\
\hline 4.03.10.10 TRASF. DI CAPIT. ORD. DALLA REGIONE & $476.033,04$ & 70,1 & $495.300,65$ & 8,18 & $25.000,00$ & 1,32 & $159.561,55$ & 2,45 & $74.681,83$ & 2,42 \\
\hline 4.03.10.20 TRASF. DI CAPIT. STRA. DALLA REGIONE & & & $273.557,57$ & 4,52 & 1.143.195,67 & 60,4 & $4.807 .028,07$ & 73,8 & $1.600 .145,54$ & 51,9 \\
\hline 4.05.10.50 PROVENTI CONC. EDILIZIE E SANZ.URBAN & $203.142,35$ & 29,9 & $338.143,29$ & 5,58 & $722.209,82$ & 38,2 & $911.762,35$ & 14 & $1.386 .780,72$ & 45 \\
\hline Totale Titolo & $679.175,39$ & 100 & $6.057 .543,14$ & 100 & $1.892 .685,64$ & 99,9 & $6.515 .151,81$ & 100 & $3.084 .863,02$ & 100 \\
\hline
\end{tabular}

Table 3 : Expenditures

\begin{tabular}{|c|c|c|c|c|c|c|c|c|c|c|}
\hline \multirow{2}{*}{ Expenditures } & \multicolumn{2}{|l|}{2012} & \multicolumn{2}{|l|}{2011} & \multicolumn{2}{|l|}{2010} & \multicolumn{2}{|l|}{2009} & \multicolumn{2}{|l|}{2008} \\
\hline & $€$ & $\%$ & $€$ & $\%$ & $€$ & $\%$ & $\epsilon$ & $\%$ & $€$ & $\%$ \\
\hline TITOLO I - SPESE CORRENTI & $7.493 .383,35$ & 60 & $8.166 .961,65$ & 44 & $8.746 .589,93$ & 61 & $8.391 .762,50$ & 48 & $8.372 .759,40$ & 56 \\
\hline TITOLO II - SPESE IN CONTO CAPITALE & $2.061 .523,85$ & 17 & $3.977 .030,34$ & 21 & $2.660 .455,03$ & 19 & $5.493 .999,60$ & 32 & $2.190 .041,58$ & 15 \\
\hline TITOLO III - SPESE PER RIMBORSO DI PRESTITI & $155.593,06$ & 1 & $4.813 .758,86$ & 26 & 1.005.167,15 & 7 & $484.158,27$ & 3 & $2.440 .139,75$ & 16 \\
\hline TITOLO IV - SPESE PER SERVIZI PER CONTO DI TERA & $2.770 .135,47$ & 22 & $1.772 .743,18$ & 9 & $1.959 .233,43$ & 14 & $3.012 .651,11$ & 17 & $2.011 .693,91$ & 13 \\
\hline TOTALE TITOLI SPESA & $12.480 .635,73$ & 100 & $18.730 .494,03$ & 100 & 14.371.445,54 & 100 & 17.382.571,48 & 100 & $15.014 .634,64$ & 100 \\
\hline
\end{tabular}

"Concession fees and sanctions" revenues represent an important resource for a Municipality that, in 2011, fell into financial imbalance (as many others in the province of Caserta). For the concession fees, the Local Authority recently has provided to the adjustment and updating of the fees with Municipal Resolution n.5/2013 that, highlighting the gap between the real costs of public facilities, (increased in the last years and the charges), establish the updating of parametric schedules for primary and secondary urbanizations as well as for the construction costs.

However, as for the sanctions, it is urgent and necessary to proceed in the examination of the demands for building sanctions that are still unsold. This kind of revenue, in a municipality characterized by a high concentration of unauthorized buildings and scarce equipment and qualities of public facilities and services, could represent a significant opportunity to collect financial resources, "in order to improve both the efficiency and effectiveness of public services provided to the citizens" [12].

Finally, considering that the illegal building phenomenon also constitutes a particular form of "real estate submarket", analyzing the municipality of Casal di Principe in terms of market value of residential buildings, over the period 2012-2002 (using the database for real estate market prices run by the Agenzia del Territorio - Land Registry- through OMI - Real Estate Observatory) it is possible to deduce a not particularly dynamic trend and a modest market appreciation (bad quality of buildings, absence of public facilities and services, etc.). The difference between central (B) semi central (C) and peripheral zones (D) is very low (see Figure 2 and Tables 4); in this last area, indicated in the Master Plan (Figure 3) as homogeneous zone D2 - productive, artisanal and commercial zone - several unauthorized buildings are localized. Moreover, in the zone indicated as Zone E (agricultural of urban safeguard), there is a high presence of unauthorized buildings that constitute a particular form of real estate submarket. The scarce transparency of the urban real estate market does not allow to distinguish among a market of legal products and a "submarket of illegal products", object of sanctions and, indeed, of appraisal.

This observations allows to highlight what Carlo Forte wrote in the far 1970: <<The auspice is that the evaluation of pecuniary sanction for illegal buildings will be, in the future, a more and more infrequent eventuality in the appraisal survey as a result of a different urban planning awareness which will guarantee the respect of norms and laws $>>$. [13]. However, the actuality clearly demonstrates the degeneration of the phenomenon. 


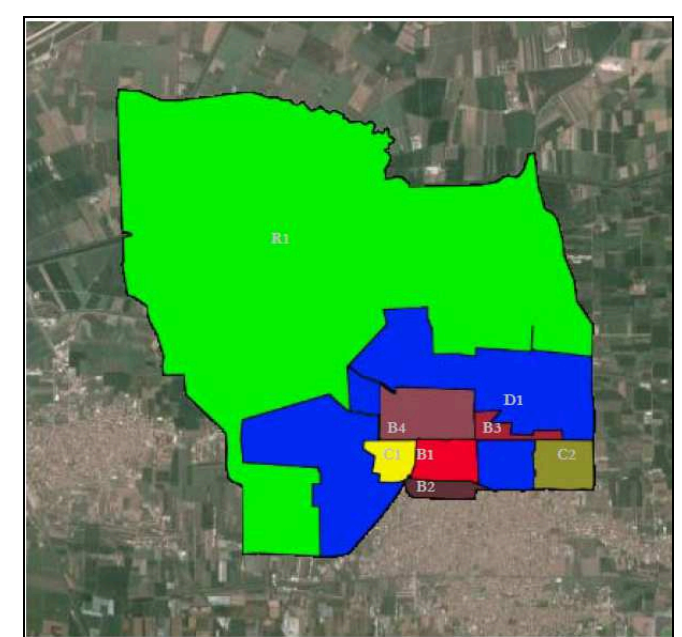

Figure 2: Casal di Principe OMI zones

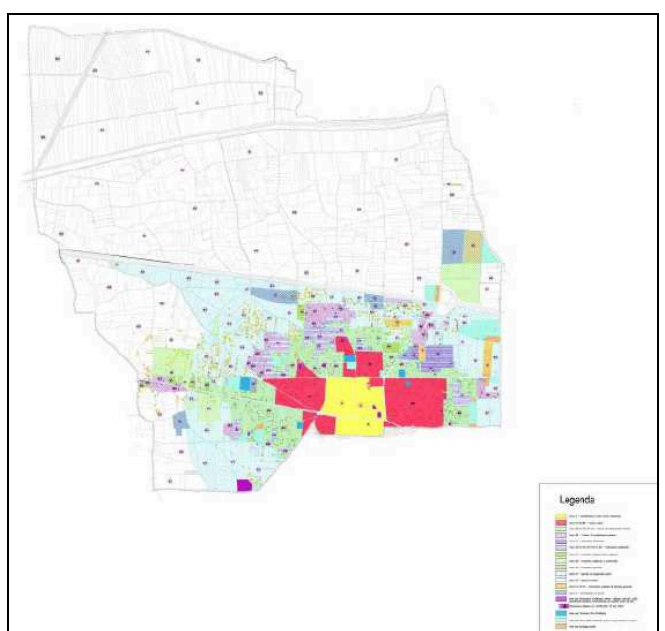

Figure 3: Master Plan

Tables 4: Casal di Principe micro zones and residential building market values trend (source: Land Registry, Agenzia del Territorio,)

\begin{tabular}{|c|c|c|c|c|c|c|c|c|c|c|c|c|c|c|c|c|c|c|c|c|}
\hline MI & & 2012 & & 011 & & 2010 & & 009 & & 008 & & 007 & & 006 & & 005 & & 004 & 2003 & 2002 \\
\hline B & $€$ & .050 & $\epsilon$ & 900 & $€$ & 950 & $€$ & 950 & $I^{2}$ & 800 & $€$ & 600 & $€$ & 600 & & 430 & & & $€ \quad 410$ & $€ \quad 410$ \\
\hline B2 & $€$ & 1.050 & $€$ & 860 & $€$ & 900 & $€$ & 900 & $€$ & 800 & $€$ & 800 & $€$ & 800 & $€$ & 600 & $€$ & 600 & 570 & $€ \quad 570$ \\
\hline B3 & $€$ & 1.050 & $€$ & 760 & $€$ & 800 & $€$ & 800 & $€$ & 800 & $€$ & 800 & $€$ & 800 & $€$ & 600 & $€$ & 600 & $€ \quad 570$ & $€ \quad 570$ \\
\hline B4 & $€$ & 1.050 & $€$ & 950 & $€$ & 1.000 & $€$ & 1.000 & $€$ & 800 & $€$ & 600 & $€$ & 600 & $€$ & 430 & $€$ & 430 & $€ \quad 410$ & $€ \quad 410$ \\
\hline $\mathrm{C} 1$ & $€$ & 1.200 & $€$ & 760 & $€$ & 800 & $€$ & 800 & $€$ & 800 & $€$ & 800 & $€$ & 800 & $€$ & 820 & $\epsilon$ & 600 & $€ \quad 570$ & $€ \quad 570$ \\
\hline C & $€$ & 960 & $€$ & 760 & $€$ & 800 & $€$ & 800 & $€$ & 800 & $€$ & 800 & $€$ & 800 & $€$ & 600 & $€$ & 600 & $€ 520$ & $€ \quad 520$ \\
\hline$D 1$ & & 900 & $€$ & 760 & $€$ & 800 & $€$ & 800 & $€$ & 800 & $€$ & 800 & $€$ & 800 & $€$ & 550 & & 550 & $€ \quad 670$ & $€ \quad 670$ \\
\hline
\end{tabular}

\section{Some conclusions}

The realization of Metropolitan Cities requires resources, interests and actors [14] because the resources available for the realization of community facilities and services are scarce, especially in the current economic conjuncture. In light of a growing problem which is that of illegal buildings and soil consumption, it is no longer possible to continue to ignore financial tools that, in numerous municipalities of the arising Metropolitan City, may allow for the recovery of liveability for the community that is widely impaired. If Metropolitan City must supply the municipalities that compose it and these municipalities must play an important role inside its quality of life and development [15], they must necessarily work in a perspective of efficiency and effectiveness for the sustainable management of the metropolitan territory.

Moreover, the illegal building phenomenon results very serious. Considering the severe situation in the Campania Region and especially in the provinces of Naples and Caserta, the research activity will proceed with a rigorous census and updating activities, nowadays ever more supported by GIS, together with a survey of the Technical Offices of the municipalities object of analysis, in a more general perspective of "reading the municipal budgets for reading territories" [16].

\section{References}

[1] United Nations, Self-made Cities, In Search of Sustainable Solutions for Informal Settlements in the United Nations, Economic Commission for Europe Region, (2009)

[2] ISTAT, BES 2013, Il benessere equo e sostenibile in Italia, Istata-Cnel, (2013)

[3] M. Giudice, F. Minucci: Il consumo di suolo in Italia. Analisi e prospettive per un governo sostenibile del territorio, Esselibri Simone (2011); S. Lo Nardo, A. Vedaschi (eds), Consumo del territorio, crisi del paesaggio e finanza locale. Verso una nuova urbanistica, Gangemi Editore (2011) 
[4] Fr. Forte: Innovare coltivando fermezza e speranza: la città metropolitana campana, luglio 2013. Information on: www.fforteprof.net

[5] E. Slack: Financing Large Cities and Metropolitan Areas, Institute on Municipal Finance and Governance, Munk School of Global Affairs, University of Toronto, December 2010

[6] S. Stanghellini: Le sfide dell'urbanistica riformista: consumo di suolo, demanio, oneri e fisco, In: M. Leonori, P. Testa (eds), La città oltre lo sprawl, Rendita, consumo di suolo e politiche urbane ai tempi della crisi, Italianieuropei- Cittalia (2013)

[7] R. Camagni: Le aree metropolitane italiane per lo sviluppo del paese: obiettivi e competenze nella nuova legge. In: Le città metropolitane: una riforma per il rilancio del paese, Convegno organizzato dalla RETE delle Associazioni Industriali Metropolitane, Firenze (2014)

[8] G. De Mare, I. Fasolino, B. Ferrara: Abusivismo edilizio: ipotesi metodologica di rifunzionalizzazione urbana. Information on www.e-stimo.it, online journal (2010)

[9] UN-HABITAT, Guide to Municipal Finance, Nairobi (2009)

[10] Legambiente, Ecomafia 2012, The environmental illegality and the role of crime organizations, Legambiente Environmental Crimes National Dept (2012)

[11] C. De Biase, F. Forte: Unauthorised building and financial recovery of urban areas: evidences from Caserta Area, Euromed (2013)

[12] L. Boetti, M. Piacenza, G. Turati: Decentralization and local government's performance: how does fiscal autonomy affect spending efficiency?, Department of Economics and Public Finance "G. Prato", Working paper series, Working paper No. 11 - March 2010

[13] C. Forte: La stima della sanzione pecuniaria per opere abusivamente eseguite. In: Rivista del Catasto e dei Servizi Tecnici Erariali, anno XXV- nn.4-5-6, Roma (1970)

[14] V. Ferri: Le città metropolitane in Italia. Un istituzione del federalismo. In: Economia italiana, 2009/2 Maggio-Agosto, pp.389-426

[15] B. Dente: Il governo delle metropoli italiane. In: R. Florio, A. Esposito (eds): La costruzione della città metropolitana in Italia. Esperienze, soluzioni e prospettive, ReCS, Rete delle città strategiche, Firenze maggio (2012)

[16] M. Betti, F. Moroni, in collaborazione con R. Nerio: Leggere i bilanci per leggere i territori: l'edilizia comunale in superfici, volumi, euro, Regione Emilia Romagna (2012) 